\title{
The Development of Cross-faculty/University Integrated Social Science Learning Model in the Faculty of Social Science, Universitas Negeri Medan
}

DOI: https://doi.org/10.47175/rielsj.v2i2.262

\section{| Nurmala Berutuํㅣ | Muhammad Ridha Syafii Damanik² | | Maryatun Kabatiah ${ }^{3}$ |}

1,2,3 Faculty of Social Sciences, Universitas Negeri Medan, Medan, Indonesia

"nurmalaberut@unimed.ac.id

\begin{abstract}
The development of Industrial Revolution 4.0 has implications for all areas, including education. One of the emerging indicators is the application of the independent learning curriculum. Every human being has the right to learn wherever and whenever this is in accordance with the conceptual application of the curriculum. This research aims to develop an integrated social science learning model between faculties/universities that will be used to succeed in the independent learning curriculum at the Faculty of Social Sciences of Medan State University (FIS UNIMED). The research is research and development in the field of education that uses data collection techniques using documentation studies, interviews, and workshops, the data sources used are lecturers and students of FIS UNIMED. The research stage refers to the R\&D research stage (Gall, Borg, \& Gall,) [5], the stages performed include: 1) Research Planning 2) Subject Determination Model 3) Preparing Learning Tools for Model 4 Courses)) Input Course Content into LMS 5) Testing (simulation) and evaluation of Content 6) Follow-up improvements 7) Dissemination. The results of the analysis show that the development of model courses as part of the integrated social science learning model across faculties/universities in preparation for independent learning in FIS UNIMED based on 4 criteria for learning models, namely 1)field-based learning in the Anthropology education Study Program 2) practice-based learning in the Geography Education Study Program 3) seminar-based learning in the Historical Education Study Program and 4) attitudebased learning in the Civic Education Study Program is very practical. The average practicality score of this model is based on students 'and lecturers' responses was 85, which categorized as very practical. Thus, the learning model course that has been developed will be used as a prototype for other courses at FIS UNIMED in the framework of implementing the curriculum for independent learning in the future.

KEYWORDS

Integrated; social; science; learning; model; independent
\end{abstract}

\section{INTRODUCTION}

In demanding of current changes, and the need for a link and match with the business world and the industrial world (DU / DI), and to prepare students for the world of work, universities are required to be able to design and implement innovative learning processes. Based on the constructivist paradigm, innovative learning is where students are able to update the information where they get from the learning process. Where the process of re-creation 
occurs through new creation and knowledge which is the result of new thinking (Gardner, 1991).

According to Muslich (2007), innovative learning is: (a) learning from reality that is commonly observed, practiced, and experienced in life (real world learning), (b) learning through real experiences that are carried out empirically, (c) generating knowledge that meaningful (meaningful), and (d) using various assessment techniques (not only tests). In addition, Blanchard (in Haryono, 2015) asserts that innovative learning includes six elements, namely: meaningful learning, application of knowledge, higher-order thinking, curriculum based on standards, responsive to culture, and using authentic assessment.

In order to students can reach learning achievements which includes aspects of attitude, knowledge, and skills optimally. The Independent Learning Policy is expected to be the key to answer these demands. According to the Ministry of Education and Culture, the Independent Campus is an independent and flexible learning in Campus education so it will create a learning culture that is very innovative, does not have limits, and follows as the needs of students (Direktorat Jenderal Pendidikan Tinggi Kemendikbud RI, 2020).

The process so that students can achieve learning achievement that includes aspects of attitudes, knowledge, and skills optimally. So, the Independent Learning Policy is expected to be the answer to these demands. Independent learning itself has the essence that students will have the freedom to think either individually or in groups, so that in the future they can give birth to students who are superior, critical, creative, collaborative, innovative, and participating. It is hoped that with the independent learning program there will be an increase in the involvement of students in learning. (Siregar et al., 2020).

The self-study program policy was launched at the university level. The free study program for the university level is called the Independent Learning Campus. In the independent learning campus program there are various kinds of activities that can be carried out by students, one example of these activities is the Pioneer Teaching Campus (KMP) program. Independent Campus is also as a form of autonomous and flexible learning in higher education so as to create a learning culture that is innovative, does not limit, and follows the needs of students (Directorate General of Higher Education Kemendikbud RI, 2020).

The existence of this demand must be responded well by every member of the community, from the leadership level to students as the main consumers. So far, the Faculty of Social Sciences, Universitas Negeri Medan, has implemented blended learning, where face-to-face meetings in rooms collaborate with online or online learning. However, its effectiveness is still not optimal. Lecturers still have not fully optimized the learning resources in the lecture process, as well as students tend to be more rigid in utilizing widely open learning sources. In this independent learning era, it is hoped that lecturers and students can optimize learning resources both in terms of materials and in terms of utilization of cross-institutional stakeholders. This research aims to conduct the development related to social science learning models integrated between faculties/universities which will later be used to make successful the independent learning curriculum at the Faculty of Social Sciences (FIS), Universitas Negeri Medan (UNIMED).

\section{REVIEW OF LITERATURE}

\section{Independent Learning-Independent Campus}

In early 2020 the Ministry of Education and Culture issued the Independent LearningIndependent Campus (Merdeka Belajar Kampus Merdekal MBKM) policy. The MBKM policy generally provides study rights for undergraduate and applied undergraduate students for three (3) semesters outside the study program. 
In practice, students can voluntarily study in out of University for 1 (one) semester or equivalent to 20 (twenty) credits; and a maximum of 2 (two) semesters or equivalent to 40 (forty) credits of studying in the same study program outside the University, studying in the different study programs at different universities; and/or learning outside the university.

Calculating of semester credit units (credits) for learning activities outside the campus is calculated based on the number of hours of activity. One (1) credit is equivalent to 170 minutes per week per semester.

The MBKM policy is implemented in order to realize an independent and flexible learning process in Campus education so that universities can design and implement innovative learning processes so that students can achieve learning outcomes covering aspects of attitudes, knowledge, and skills optimally.

Furthermore, the MBKM policy aims to improve the competence of graduates, both soft skills and hard skills to be more prepared and relevant to the needs of the times, as well as prepare graduates as future leaders of the nation with excellent and personality.

Learning process activities outside the study program within the Merdeka Campus include: internships or work practices, village projects, student exchanges, research, entrepreneurship, independent studies, humanitarian projects and teaching in schools. These activities can be managed by the study program or under the coordination of the relevant directorate within the University.

There are eight activities in out of campus which one can be chosen by students for independent learning project, such as; 1. Teaching in the school, 2. Internship in the Industrial Company, 3. Project in Village, 4. Entrepreneur, 5. Student Exchange, 6. Humanity Project, 7. Research, and 8. Independent project.

\section{$R \& D$ research stages}

Research \& development (research \& development) are two terms refer to the same thing, namely so that the results of conducting research from these two terms can contribute to science (theoretical contributions) which are equally important by being able to also contribute to product improvement (practical contributions).

For example, according to the Puslitjaknov Team (2008) that the notion of development research in the field of education (in research on the development of learning innovation) is a research method that contains 3 main components, namely: (1)

Development Model, (2) Development Procedure, and (3) Model or Product Development Trial; while Borg and Gall (1983) stated: "educational research and development, $\mathrm{R} \& \mathrm{D}$, is a process used to develop and validate educational products"

The process used to develop and validate educational products; Richey \& Client (2007) stated that to create an educational product requires three creations, namely a systematic study, a development process, and an evaluation aimed at making an empirical foundation. Gay, Mills \& Airasian (2009) state that the process of researching consumer needs and then developing products to meet those needs. The aim of $R \& D$ efforts in education is not to formulate or test theories but to develop products that are effective for use. The process of researching customer needs and then developing products to meet those needs. The purpose of $\mathrm{R} \& \mathrm{D}$ in education is not to formulate or test theory, but to develop effective products for use in schools).

\section{RESEARCH METHODS}

The study is a Research and Development in the field of education that used data collection techniques using documentation studies, interviews, and workshops. The population in this study is all study programs in FIS UNIMED, the data sources used are lecturers and students 
of FIS UNIMED. A cross-faculty/university learning model that is designed in the form of online learning and policies at the faculty level which will later be applied to each course. The research stages refer to the R\&D research stages (Gall, Borg, \& Gall, 1996).

\section{RESULTS AND DISCUSSION}

The objective of the independent Learning-Independent campus policy, the program "three semesters of study rights outside the study program" is to improve the competence of the best graduates, both soft skills and hard skills, so that they are more capable and ready to compete with the times and are relevant to the needs of the times, and prepare graduates as future leaders of the nation who are superior, and have good personalities. The experiential learning program with a flexible path is expected to facilitate students to develop their potential according to their passions and talents. (Direktorat Jenderal Pendidikan Tinggi Kemendikbud RI, 2020).

Responding to this, a review was carried out on the distribution of the curriculum and optimization of the existing LMS for each study program at the FIS UNIMED, namely the History Education Study Program, Citizenship Education, Geography Education, and Anthropology Education, the activity began with a cluster inventory of subjects in each semester. The following is the flow of the model development that has been carried out: model development that has been carried out:

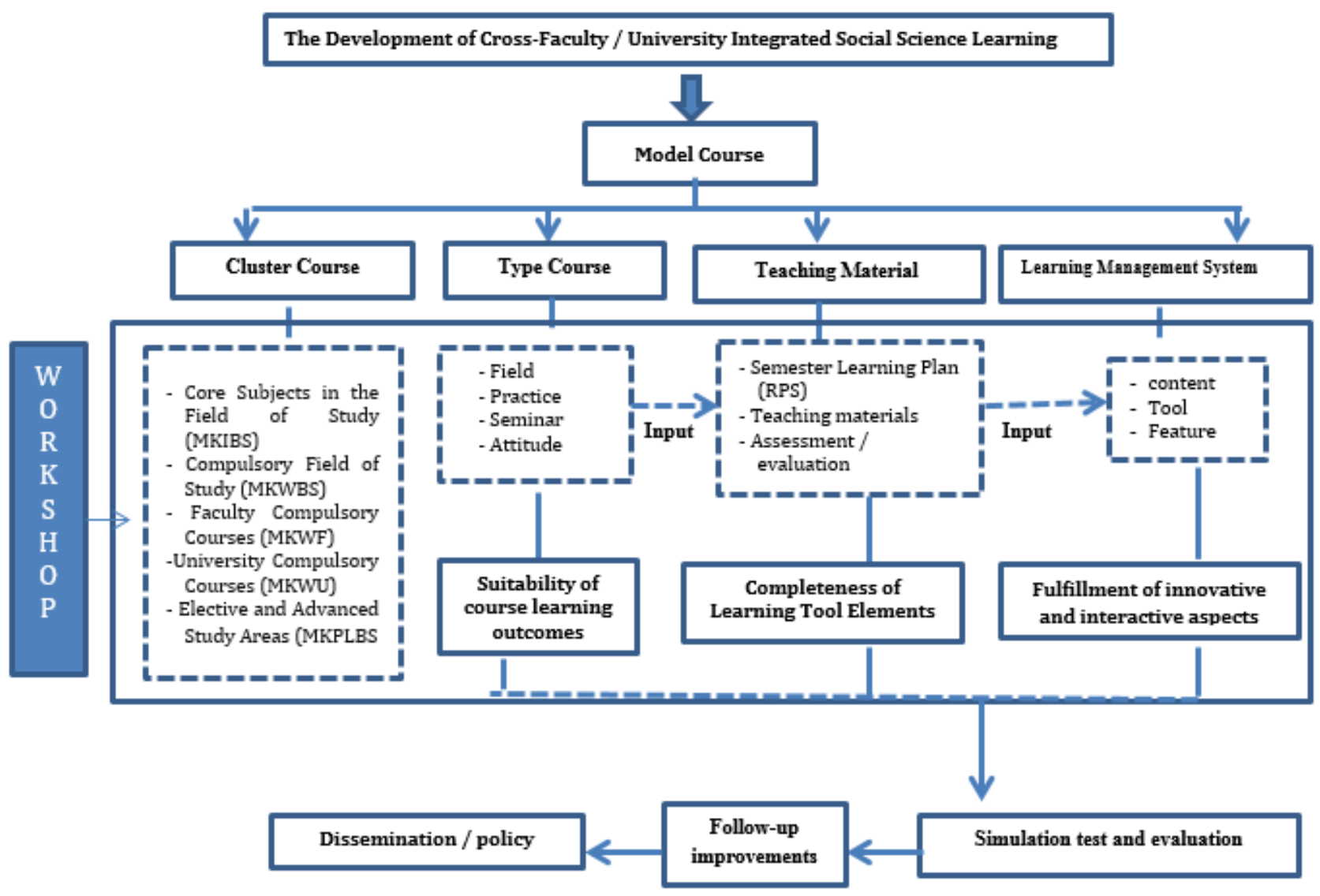

Figure 1. The Flow of development model 
The course cluster aims to divide courses based on their nature and urgency in forming the CPL study program. The division of subject clusters for each study program in the table above is based on the following provisions: 1) Core Subjects in the Field of Study (MKIBS) a minimum of 90 credits, 2) Compulsory Subjects in the Field of Study at least 10 credits, 3) Faculty Compulsory Courses (MKWF) a maximum of 8 credits, 4) 12 credits of Compulsory University Subjects (MKWU), and 5) Elective and Advanced Field of Study (MKPLBS) a maximum of 38 credits (Permendikbud, 2020). Each study program determines model courses taken from the cluster of core subject areas of study (MKIBS) as part of an integrated social science learning model across faculties/universities in preparation for independent learning at FIS UNIMED. From the workshop results, it was determined that the Anthropology Study program developed a model subject whose learning was fieldbased. The Geography Education Study Program develops a model subject whose learning is practice-based. The Historical Education Study Program develops a model subject whose learning is seminar-based and the Civics Education Study Program develops a model subject whose learning is attitude-based.

In addition to the types of courses, model courses are determined with several considerations, the readiness of course teaching materials (readiness of semester learning plans (RPS), textbooks, and other learning references), the readiness of courses in LMS (readiness for optimization of courses at LMS), and course design (suitability of learning designs with curriculum demands freedom of learning).

The learning model is closely related to the styles of students and educators. Through the learning model, educators can help students to get information, skills, ways of thinking, and express their ideas. The learning model is a pattern that is used as a guide in planning classroom learning or tutorial learning (Trianto, 2007). With the rapid advancement of technology, the development of education is increasingly changing and encouraging various change efforts to improve the quality of education. In this case, it becomes a necessity for educational institutions to be able to develop a Learning Management System (LMS) as a learning medium using available open sources. According to Ryan K. Ellis (2009) Learning Management System, the basic description is a software application that automates the administration, tracking, and reporting of training events. LMS is used to create learning materials and manage all learning activities and their results based online on the web. This LMS is often referred to as an e-learning platform or learning content management system (LCMS). In essence, LMS is an application that simplifies the virtual and electronic teaching and learning process automatically.

Therefore, it is very important for lecturers who teach courses to be able to manage their LMS courses properly, in developing the model subject improvements, content, tools, and features in this case online learning system UNIMED (SIPDA-UNIMED) as the official united online learning LMS platform. The improvement of the LMS for courses aims to optimize online learning in model courses that can be used as a reference for determining quality manuals or online learning operational standards for other courses at FIS UNIMED. Among them, the LMS content must contain an introduction, lecture rules or ethics, RPS, class activities for 16 meetings, references, assignments, initiations, and assessments. LMS contains features for web meetings, virtual chat, discussion forums, etc. In using tools or platforms, it is necessary to pay attention to the situations and conditions in which a learning event can occur (learning settings) and learning activities. Learning settings consist of two categories, namely synchronous learning (synchronous learning), either direct synchronous or virtual synchronous or asynchronous learning (Asynchronous Learning). In the LMS, all subject models and integrated social studies learning tools are included to be applied in independent learning. Where this LMS can be accessed by students and lecturers anywhere 
and anytime according to learning needs. This is done in accordance with the objectives and the independent learning program from the Ministry of Education and Culture and LMS can support the program.

Table 1. The practicality of the learning model

\begin{tabular}{lll}
\hline INDICATOR & $\begin{array}{l}\text { AVERAGE } \\
\text { PRACTICAL } \\
\text { VALUE }\end{array}$ & CRITERIA \\
\hline $\begin{array}{l}\text { Ease of use of media and } \\
\text { access to courses at LMS }\end{array}$ & $87 \%$ & Very Practical \\
$\begin{array}{l}\text { Instructions in class subjects } \\
\text { are easy to understand }\end{array}$ & $85 \%$ & Very Practical \\
$\begin{array}{l}\text { Informative and interactive } \\
\begin{array}{l}\text { Attractiveness } \\
\text { Completeness of learning } \\
\text { elements and assignments for } \\
\text { one semester }\end{array}\end{array}$ & $84 \%$ & Very Practical \\
$\begin{array}{l}\text { Time efficiency } \\
\text { Can be used as independent } \\
\text { learning }\end{array}$ & $84 \%$ & Very Practical \\
Total & $85 \%$ & Very Practical \\
\hline
\end{tabular}

From the results of simulations and trials that have been carried out on the model subject, it is found that the average practicality score of this model is based on students 'and lecturers' responses was 85 , which categorized as very practical. So, the integrated social studies subject at UNIMED Faculty of Social Sciences were developed in accordance with current and future needs as a prototype of subject with an independent learning curriculum in the future, is as an answer to the challenges in the industrial revolution 4.0 era. The practicality of the integrated social studies learning model across faculties/ university, optimal LMS management is expected to be an element that supports the efficiency and effectiveness of independent learning.

\section{CONCLUSION}

The results of the analysis show that the development of model courses as part of the integrated social science learning model across faculties/universities in preparation for independent learning in FIS UNIMED based on 4 criteria for learning models, namely 1) field-based learning in the Anthropology education Study Program 2) practice-based learning in the Geography Education Study Program 3) seminar-based learning in the Historical Education Study Program and 4) attitude-based learning in the Civic Education Study Program is very practical. The average practicality score of this model is based on students 'and lecturers' responses was 85. Thus, the learning model course that has been developed will be used as a prototype for other courses at FIS UNIMED in the framework of implementing the curriculum for independent learning in the future.

\section{ACKNOWLEDGMENT}

This research is inseparable from the assistance of various parties, therefore we from the research team would like to thank UNIMED Leaders and their staff and the Institute for Research and Community Service (LPPM) UNIMED who have provided financial support, facilities, and infrastructure, so that the research stage this can be done well. We would also 
like to thank all parties involved in this research, namely the leaders of the faculty of social science UNIMED and their staff, the lecturers, and all the students involved.

\section{REFERENCES}

Borg. W.R. \& Gall, M.D. (1983). Educational Research: An Introduction, New York: Longman.

Direktorat Jenderal Pendidikan Tinggi Kemendikbud RI. (2020). Panduan Merdeka Belajar -Kampus Merdeka.

Hariyono . (2015). Metode Penelitian Pendidikan. Bandung: Alfabeta

Gardner, H. (1991). The unschooled mind: How children think and how schools should teach. New York: Basic Books.

Gall, M. D., Borg, W. R., \& Gall, J. P. (1996). Educational research: An introduction, 6th ed.Educational research: An introduction, 6th ed.

Muslich, M. (2007). KTSP, Pembelajaran Berbasis Kompetensi dan Inovatif. Jakarta: Bumi Aksara.

Permendikbud Nomor 3 Tahun 2020 tentang Standar Nasional Pendidikan Tinggi. (2020).

Ryan K.Ellis. (2009). A Field Guide to Learning Management System

Richey, R. C., \& Klein, J. (2007). Design and Development Research: Methods, Strategies, and Issues. Mahwah, NJ: Lawrence Erlbaum Associates, Publishers.

Richey, R.C. \& Klein. (2007). Design and Development Research. London: Lawrence Erlbaum Associates.Inc.

Sugiyono. (2010). Metode Penelitian Pendidikan. Bandung: Alfabeta.

Trianto. (2007). Mendesain Model Pembelajaran novatif Progresif. Surabaya : Kencana Prenada Media Group.

Winata, K. A., Suhartini, A., \& Ahmad, N. (2021). Development of Curriculum and Learning System in Pondok Pesantren. (A Case Study at Pesantren Al Falah Dago Bandung). Randwick International of Education and Linguistics Science Journal, 2(1), 29-36. https://doi.org/10.47175/rielsj.v2i1. 